\title{
Acute coronary syndrome: differences in men and women
}

\author{
(1) Jozica Šikić* \\ DEdvard Galić, \\ (D) Jasna Čerkez Habek, \\ DDean Strinić, \\ OZrinka Planinić
}

University Hospital "Sveti Duh“, Zagreb, Croatia
RECEIVED:

November 14, 2020

ACCEPTED:

December 18, 2020

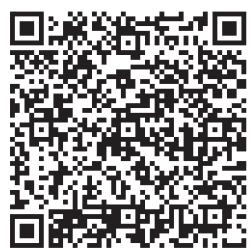

$\square$ Cardiologia Croatica 2021;16(1-2):8
KEYWORDS: acute coronary syndrome, women, man.

CITATION: Cardiol Croat. 2021;16(1-2):8. | https://doi.org/10.15836/ccar2021.8

*ADDRESS FOR CORRESPONDENCE: Jozica Šikić, Klinička bolnica "Sveti Duh“, Sv. Duh 64, HR-10000 Zagreb, Croatia. / Phone: +385-98807909 / E-mail: josicas1@gmail.com

ORCID: Jozica Šikić, https://orcid.org/0000-0003-4488-0559 • Edvard Galić, https://orcid.org/0000-0002-5707-0961 Jasna Čerkez Habek, https://orcid.org/0000-0003-3177-3797 • Dean Strinić, https://orcid.org/0000-0001-6345-2037 Zrinka Planinić, https://orcid.org/0000-0001-8664-3338

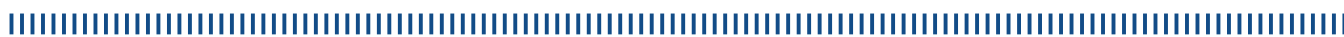

Aim: To study the impact of age and sex-related differences in patients with acute coronary syndrome (ACS) undergoing percutaneous coronary intervention (PCI).

Methods and Results: From March 2017 to November 2019, 9106 patients (6309 men and 2797 women) with ACS from 13 PCI centers were enrolled in this study (STENOS Registry). Among enrolled patients, men (69\%) were younger than women (63y vs. 68y, P=0.001), with a higher prevalence of previous myocardial infarction ( $15 \%$ vs $9.5 \% \mathrm{P}<0.001)$, previous PCI $(15.9$ vs. $9.7 \%, \mathrm{P}=0.003)$, and similar frequency of previous cerebrovascular insult and peripheral artery disease (PAD). The most affected coronary artery was proximal and mid left anterior descending (LAD) in both gender and all ages. PCI on coronary artery bypass (CABG) was performed in $0.3 \%$ ( $0.3 \%$ in men vs $0.18 \%$ in women). In patients under age 55 , $25 \%$ of men vs $11 \%$ of women ( $\mathrm{p}<0.001$ ) have had ACS. Radial approach has been done in $81 \%$, and in $89 \%$ (87.7\% in men and $88.9 \%$ in women) stent has been implanted. Average stent length was $22.01 \times 2.99 \mathrm{~mm}$ in men vs $20.7 \times 3.17 \mathrm{~mm}$ in women. Women have had $3 \%$ of unsuccessful procedures, in comparison to $2.3 \%$ in men. Restenosis rate was $3.9 \%$, and more often in men ( $4.8 \% \mathrm{vs} 2.7 \%, \mathrm{p}<0.001)$. The highest restenosis rate was between 55-80 y in men, and between 66-80 y in women. Clopidogrel was the drug of choice in $56.49 \%$. There was no difference in blood complications. In-hospital mortality rate for patients with ST-segment elevation myocardial infarction was 5.2\%, without gender differences.

Conclusion: Although there were no differences between men and women in management and inhospital outcomes, gender was shown to be predictor of earlier occurrence of ACS, higher restenosis and re-ACS rate. ${ }^{1,2}$

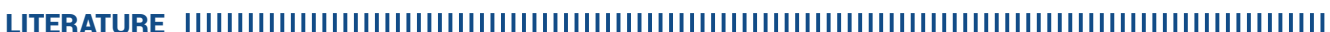

1. Haider A, Bengs S, Luu J, Osto E, Siller-Matula JM, Muka T, Gebhard C. Sex and gender in cardiovascular medicine: presentation and outcomes of acute coronary syndrome. Eur Heart J. 2020 Apr 1;41(13):1328-1336. https://doi.org/10.1093/eurheartj/ehz898

2. Gudnadottir GS, Andersen K, Thrainsdottir IS, James SK, Lagerqvist B, Gudnason T. Gender differences in coronary angiography, subsequent interventions, and outcomes among patients with acute coronary syndromes. Am Heart J. 2017 Sep;191:65-74. https://doi.org/10.1016/j.ahj.2017.06.014 